\title{
Historický vývoj pojetí didaktiky fyziky v České republice ${ }^{1}$
}

\author{
Vojtěch Žák \\ Univerzita Karlova v Praze, Matematicko-fyzikální fakulta, Katedra didaktiky fyziky
}

Redakci zasláno 5. 11. 2013 / upravená verze obdržena 25. 2. 2014 / k uveřejnění přijato 1.4 .2014

\begin{abstract}
Abstrakt: Cílem přehledové studie je popsat pojetí didaktiky fyziky, která se objevila v domácím prostředí během jejího historického vývoje, a diskutovat zejména vztah pojetí didaktiky fyziky $\mathrm{k}$ dalším oborům. To by mělo přispět k pochopení současné situace a prognóze budoucího vývoje. Ve stěžejní části studie jsou charakterizována jednotlivá pojetí české didaktiky fyziky. V chronologickém pořadí to jsou metodické, aplikační, integrační a komunikační pojetí. Ve shrnutí a závěrečné diskuzi je řešen zejména vztah pojetí didaktiky fyziky $\mathrm{k}$ fyzice, pedagogice a dalším oborům. Ukazuje se, že metodické pojetí je velmi těsně spjato s fyzikou, zatímco aplikační pojetí vychází primárně z pedagogiky. Integrační pojetí usiluje o využití také dalších věd pro rozvoj didaktiky fyziky. Ze studie vyplývá, že nejpropracovanější je komunikační pojetí. To patří ke koncepcím, které nejvýznamnějším způsobem ovlivňují současné didaktické myšlení v České republice, a to v různých oborech (také v rámci didaktik sociálněhumanitních oborů). Přes vliv komunikačního pojetí je třeba připustit, že také ostatní zmíněná pojetí se do určité míry uplatňují a v současnosti dochází k jejich koexistenci.
\end{abstract}

Klíčová slova: pojetí didaktiky fyziky, didaktika fyziky, oborová didaktika

Zdá se, že v posledních letech ožívá v České republice zájem o problematiku oborových didaktik. Hmatatelnými důkazy toho je zejména prostor věnovaný tomuto tématu v rámci odborných, především pedagogických časopisů. Jako konkrétní příklady uved'me v první řadě monotematické číslo časopisu Pedagogická orientace, 21(2) z roku 2011 (Stuchlíková \& Janík, 2011) přinášející studie několika oborových didaktiček a didaktiků (Beneš, 2011; Nezvalová, 2011; Píšová, 2011; Slavík, 2011; Stehlíková \& Tichá, 2011). Vlivné př́spěvky, které z jistého úhlu pohledu systematicky a koncepčně diskutují oborové didaktiky, najdeme také v dalších domácích odborných časopisech, např. Janík a Slavík (2007) nebo Slavík a Janík (2009).

1 Tato studie vznikla na základě autorovy diplomové práce (Žák, 2013) obhájené v roce 2013 na Filozofické fakultě Univerzity Karlovy v Praze.

DOI: $10.5817 /$ PedOr2014-2-222 
Pokud jde o didaktiky př́rodovědných oborů (včetně didaktiky fyziky), otevřelo se jim počínaje rokem 2010 nové publikační médium, elektronický časopis Scientia in educatione (např. Janík \& Stuchlíková, 2010). Příspěvky diskutující a reflektující didaktiku fyziky jako obor najdeme také v časopisu Matematika-fyzika-informatika (např. Janás \& Kolářová, 2007; Lepil, 2007; Svoboda, 2007), který můžeme považovat za klasickou platformu didaktickofyzikální reflexe.

Diskuze témat spojených s didaktikou fyziky se ale neodehrávají jen v prostoru primárně určeném odborné pedagogické a didaktické veřejnosti. Jako př́klad z nedávné doby uved'me počin Československého časopisu pro fyziku (Musilová, 2012), který byl věnován výhradně fyzikálnímu vzdělávání (a to poprvé v historii časopisu). Z editorialu tohoto dvojčísla citujme Musilovou (2012, s. 279):

Budoucnost našeho oboru² se totiž formuje nejen na vysoce specializovaných výzkumných pracovištích, ale možná v ještě větší míře v hodinách fyziky (a samozřejmě matematiky, chemie a dalších přírodovědných a technických předmětů) na všech typech škol.

Zdá se tedy, že také komunita fyziků-vědců nachází důvody, proč témata a problémy týkající se fyzikálního vzdělávání (a tedy také didaktiky fyziky) komunikovat i jinými směry než jen zpět do oblasti fyzikálního vzdělávání.

Ačkoliv je již ze samotného názvu článku patrné, že se omezíme na reflexi domácího vývoje didaktiky fyziky, vyjadřujeme naději, že tato studie může být inspirativní i pro další oborové didaktiky a pedagogickou veřejnost obecně. Za dílo, které prokázalo v minulosti vliv i mimo oblast didaktiky fyziky, ačkoli bylo věnováno primárně jí, můžeme považovat Úvod do teorie a metodologie didaktiky fyziky (Fenclová, 1982). Průcha (2009, s. 636) řadí toto dílo mezi publikace s dobrou vědeckou úrovní, které vznikly v rámci tzv. socialistické pedagogiky (explicitně zmiňuje jen dalších sedm děl obdobných kvalit).

Je otázkou, jestli budeme v blízké budoucnosti svědky (nebo už jimi jsme?) většího rozvoje oborových didaktik, jak tomu bylo $\mathrm{v}$ domácím prostředí zřejmě naposledy v 80. letech 20. století (srov. Váňová, 2000, s. 329). Ambicí tohoto článku je, aby skryté (zatím ještě spíše doutnající) snahy v tomto směru (a speciálně na poli didaktiky fyziky) podnítil.

\footnotetext{
2 Míněno fyziky (pozn. autora tohoto článku).
} 
Strategickým cílem výzkumu, jehož součástí je tato studie, je reflektovat vývoj didaktiky fyziky v České republice a v zahraničí, přispět k pochopení jejího současného stavu a formulovat prognózu jejího budoucího vývoje.

Cílem této přehledové historické studie je popsat různá pojetí didaktiky fyziky $^{3}$, která se objevila $v$ domácím prostředí během jejího historického vývoje, diskutovat vztah pojetí didaktiky fyziky $\mathrm{k}$ dalším oborům a na základě toho přispět k pochopení současné situace.

Jsme si plně vědomi hlubších souvislostí vývoje domácí didaktiky fyziky s dalšími aspekty. Jedním z nich je jistě vývoj didaktiky fyziky v mezinárodním měřítku. Tuto souvislost není ovšem možné nazírat prostou komparací domácího a mezinárodního vývoje, protože v zahraničí existují (kromě národních tradic) také minimálně dvě silné mezinárodní tradice (evropská kontinentální a anglo-americká; více Žák, 2013, s. 30-37). Vědomi si této skutečnosti odkazujeme k mezinárodnímu vývoji v tomto textu jen tam, kde je zcela přímá souvislost s vývojem domácím. Zahraniční vývoj a jeho porovnání s domácím vývojem je díky své obsáhlosti a složitosti materiálem pro jinou samostatnou studii. Obdobně je $v$ textu řešena problematika souvislostí vývoje didaktiky fyziky s vývojem dalších oborových didaktik. $\mathrm{V}$ textu odkazujeme na některé souvislosti, ale systematické porovnání neprovádíme; překračuje totiž charakter této studie, která je zaměřena primárně historicky, nikoli komparačně. Tuto studii tedy chápeme jako informační přehledovou podporu dalších budoucích výzkumů (podrobněji na konci textu).

$\mathrm{V}$ tomto textu se soustředíme na impulsy vedoucí k jednotlivým pojetím, charakteristiku pojetí a jejich konkrétní projevy ve vzdělávací praxi. Dílčí diskuze tohoto tématu samozřejmě již dříve probíhaly; jsou mu věnovány části publikací citovaných v tomto textu. ${ }^{4} \mathrm{Na}$ druhou stranu se domníváme,

3 Pojem pojetí didaktiky fyziky je používán v různých odborných textech, není nám ale známo, že by byl explicitně vymezen. Můžeme ho charakterizovat tak, že zahrnuje představy didaktiků fyziky zejména o smyslu, cílech, obsahu, metodách a produktech jejich práce. Je třeba zdůraznit, že uvedené kategorie jsou v různých pojetích nejen různě syceny, ale je jim věnována také různá pozornost (včetně případu, že některé kategorii není v určitém pojetí věnována v podstatě žádná pozornost). Pojem pojetí se částečně kryje s pojmem paradigma, např. oba mají jak kognitivní, tak normativní funkci. Přesné vyšetření vztahu těchto dvou pojmů by ovšem vydalo na samostatnou studii; zejména vzhledem k tomu, že pojem paradigma (podrobněji nap̌r. Kuhn, 2008) je poměrně mnohoznačný.

4 Analýze byly podrobeny v první řadě relevantní články uveřejněné v letech 2003 až 2012 v nejvýznamnějším domácím didakticko-fyzikálním časopise Matematika-fyzika-informati- 
že v obsáhlejší a souhrnné podobě nebyl vývoj pojetí didaktiky fyziky v domácím prostředí zatím dostatečně zpracován, zejména ne ve vztahu k dalším oborům - především fyzice a pedagogice. Věříme, že poznání časového vývoje určitého fenoménu $\mathrm{v}$ těchto souvislostech může vést $\mathrm{k}$ jeho hlubšímu pochopení. Podrobná analýza současného stavu didaktiky fyziky v České republice ale přesahuje hloubkou a rozsahem nutného zpracování možnosti tohoto článku, proto se jí zde jako takové již nevěnujeme.

Tato studie je určena zejména začínajícím výzkumníkům v oblasti didaktiky fyziky (včetně doktorandů), vzdělavatelům učitelů fyziky a také dalším oborovým didaktikům, kteří mohou tuto studii využít jako pramen dalších úvah v souvislosti se svým oborem. Studie by měla být jazykově a myšlenkově přístupná také motivovanějším studentům učitelství (fyziky) a učitelům (fyziky) z praxe.

\section{Popis a diskuze jednotlivých pojetí didaktiky fyziky}

Ačkoliv historie české didaktiky fyziky je poměrně krátká, objevilo se v ní několik jejích různých pojetí. Jednotlivá pojetí uvádíme $\mathrm{v}$ chronologickém pořadí tak, jak se postupně vyskytla na domácí scéně. Je třeba upozornit, že mezi jednotlivými pojetími neexistuje ostrá hranice - ani obsahová, ani časová, která by je oddělovala. Jednotlivá pojetí bychom dokonce měli chápat spíše jako určité abstrakty, ideály, ke kterým směřovalo úsilí určitých lidí v daném období. Můžeme říci, že pojetí na sebe určitým způsobem reagují a navazují, ale také do určité míry koexistují. Pojetí, která níže uvádíme a diskutujeme, se netýkají pouze didaktiky fyziky, ale také dalších oborových didaktik (a to $\mathrm{v}$ různé míře). $\mathrm{V}$ textu tedy někdy hovoříme místo didaktiky fyziky obecněji o oborových didaktikách. Jsme si vědomi, že by si toto téma zasloužilo obsáhlejší studii, ale i tak věříme, že níže uvedený přehled a diskuze může přispět k reflexi vývoje oborových didaktik v domácím prostředí.

ka a v pěti významných českých pedagogických časopisech, za které v souladu s Marešem a Honsnejmanovou (2011) považujeme (abecedně řazeno) E-Pedagogium, Orbis scholae, Pedagogickou orientaci, Pedagogiku a Studia paedagogica. Publikace z těchto časopisů považujeme za aktuální domácí práce k tématu. Jejich seznam je uveden v práci Žáka (2013, s. 70-74). Vycházelo se tedy z toho, že závažné informace k tématu by měly být diskutovány v uplynulých přibližně deseti letech v odborných časopisech. Na základě odkazů z těchto článků se posléze přistoupilo k analýze dalších, mnohdy původních publikací. 


\subsection{Metodické pojetí ${ }^{5}$}

Jak uvádí Brockmeyerová-Fenclová, Čapek a Kotásek (2000, s. 24), systém předmětově uspořádané výuky ve školách a zavádění učebních osnov vedly od 19. století $\mathrm{k}$ tvorbě návodných a normativně pojatých příruček pro učitele jednotlivých školních předmětů. Pokud byly takové texty zpracovány do podoby soustavnějších prací, byly označovány za metodiky vyučování učebních předmětů. Tyto texty (metodiky) zprostředkovávaly zkušenost z vyučování a předepisovaly nebo návodným způsobem doporučovaly učiteli, jak má při vyučování postupovat (Kotásek, 2011, s. 228). Zabývaly se převážně otázkami způsobů a postupů výuky. Mezi tzv. metodiky řadí Kašpar (1960, s. 9) např. dílo K. Hahna Methodik des physikalischen Unterrichtes ze 20. let 20. století, které bylo využíváno také u nás.

Podle Lepila (2012, s. 5) můžeme za počátek hlubšího zájmu o daný vyučovací předmět - fyziku a o způsob, jakým je ve školách vyučován, považovat vznik prvních učebnic fyziky. Obsah a metodické zpracování českých učebnic fyziky bylo z historických důvodů silně ovlivněno učebnicemi německými. Významnou úlohu sehrávali učitelé fyziky na středních školách. Ti projevovali již v období první poloviny 20. století zájem o nové vyučovací postupy, především o názornější výklad podporovaný fyzikálními pokusy (Lepil, 2012, s. 5-6). Pokud jde o přípravu budoucích středoškolských učitelů, tak tito byli do poloviny 20. století vzděláváni na univerzitách studiem fyziky, ve kterém nebylo rozlišováno mezi učitelstvím a vědeckou prací ve fyzice. Teprve ve 30 . letech 20 . století bylo pro budoucí učitele fyziky zavedeno jednosemestrální metodické cvičení (Lepil, 2012, s. 6).

Výše naznačené pojetí bylo podle Brockmeyerové a Tarábka (2009, s. 283) pro oblast fyzikálního vzdělávání (didaktiky fyziky) charakteristické zhruba do roku 1950, tedy v období, kdy didaktika fyziky nebyla ještě nahlížena jako věda. ${ }^{6}$ Typickým atributem bylo zaměření na metody a prostředky výuky fyziky z hlediska praxe. Obdobně podle Fenclové (1982, s. 16) se česká didaktická literatura až do poloviny 20. století vyznačovala tím, že sloužila prrímo praxi ve školách a bez vědeckého př́ístupu řešila relativně úzkou problematiku, zejména vybavování fyzikálních kabinetů, zřizování fyzikálních

5 Striktně vzato se nejedná o pojetí didaktiky fyziky, ale tato fáze spíše spadá do období před konstituováním didaktiky fyziky jako oboru.

6 Uvedený časový údaj berme jako velmi orientační, protože metodické pojetí v určité podobě koexistuje dodnes (dále v závěrečném shrnutí). 
učeben, vedení fyzikálních praktik, demonstrační pokusy, příp. výklad obtížných partií fyziky.

Metodiky jako návody a komentáře k učebním osnovám však koncem 40. let 20. století (v podmínkách, kdy začali být na vysokých školách vzděláváni učitelé všech kategorií) už neodpovídaly principům, které zejména univerzity uplatňují na disciplíny na nich rozvíjené (Brockmeyerová-Fenclová, Čapek, \& Kotásek, 2000; Kotásek, 2011). Přibližně od poloviny 20. století byla univerzitám svěřována př́prava budoucích učitelů a začaly se prosazovat snahy o přeměnu tradičních lektorských kurzů metodik na svébytné disciplíny, které by stejně jako ostatní vysokoškolské obory splňovaly požadavky kladené na vědu a výzkum. Koncepce nově vznikající disciplíny navazovala podle Lepila (2012, s. 6) jak na českou tradici fyzikálního vzdělávání z období mezi dvěma světovými válkami, tak se začal projevovat rovněž vliv koncepcí, které měly svůj původ v tehdejším Sovětském svazu. U nás, v německy mluvících zemích a i v dalších zemích kontinentální Evropy byl pro tuto oblast (v souladu s myšlenkami začínajícími u Wolfganga Ratkeho a Jana Amose Komenského) použit termín didaktika (srov. Kansanen, 2007).

Obecně můžeme říci, že také další oborové didaktiky, lépe řečeno to, co jim předcházelo, se v 1 . polovině 20 . století (jak u nás, tak v zahraničí) zabývaly zejména tím, jak se má vyučovat, zatímco obsahy (co se má vyučovat) byly dány oborem. To znamená, že i v jiných oborových didaktikách šlo z vývojového hlediska nejprve o metodiky. Avšak už v tomto období, ve 20. a 30. letech 20. století, se začínal rozvíjet výzkum vyučování a učení a tím byly položeny základy skutečného oborově didaktického výzkumu. Oborové didaktiky se tedy v tomto období začínají profilovat jako zkoumající disciplíny (Janík, 2009, s. 658).

\subsection{Aplikační pojetí}

Postupem času začaly vznikat práce překonávající úzce metodické pojetí a vymezující svůj předmět ve smyslu didaktik učebních předmětů (Brockmeyerová-Fenclová et al., 2000, s. 24-25). Úsilí směřovalo také k vymezení kritérií vědeckosti těchto oborů (v české didaktice fyziky napřs. J. Fuka a E. Kašpar). $\mathrm{V}$ tomto období převládl názor, že předmět i metody těchto disciplín (tedy i didaktiky fyziky) je nutné odvozovat především z pedagogických věd. Tím jim podle Brockmeyerové-Fenclové et al. (2000, s. 27) byla přisouzena především určitá aplikační funkce. 
Hlavním přístupem byla aplikace obecných cílů výchovy a vzdělávání a obecných didaktických principů na učivo fyziky - odtud aplikační pojetí. Didaktika fyziky se teoreticky odvozovala z obecné didaktiky a byla tak speciální pedagogickou (resp. didaktickou) disciplínou, která se vztahovala k vyučovacímu předmětu fyzika (Nezvalová, 2011, s. 175). Prvořadá v tomto pojetí byla tedy obecná didaktika, fyzika se uplatňovala až na druhém místě. Jinými slovy můžeme říct, že aplikační pojetí chápalo tzv. předmětovou didaktiku jen jako konkretizaci obecné didaktiky ve výuce př́slušného školního předmětu a jako praktický důsledek k němu se vztahujícího vědního oboru (Brockmeyerová-Fenclová et at., 2000, s. 27).

Podle Nezvalové (2011, s. 174) bylo snahou především hledat metody a prostředky, které by usnadňovaly učitelům sdělovat fyzikální učivo žákům. Obdobně podle Fenclové (1982, s. 19) bylo základním cílem takto pojaté didaktiky fyziky stanovení optimálních vyučovacích postupů, a to zejména se zřetelem $\mathrm{k}$ potřebě učitelů. Toto pojetí se u nás vyvíjelo zejména v 50 . až 70. letech 20. století (Brockmeyerová \& Tarábek, 2009, s. 283).

Je ovšem otázkou, do jaké míry se podařilo rozpracovat a prosadit aplikační pojetí jako svébytnou etapu vývoje domácí didaktiky fyziky. Koncepční práce, které by se tímto pojetím jednoznačně zabývaly, nám totiž nejsou známy. Zdá se pravděpodobné, že toto pojetí zůstalo více v rovině úvah, které byly výrazem odpoutávání otázek výuky fyziky od fyziky jako vědy, s tím, že sílil vliv pedagogických disciplín. Pokus o větší vliv pedagogiky v této oblasti můžeme chápat jako dílčí krok k osamostatňování didaktiky fyziky, i když mělo vlastně dojít k nahrazení závislosti na fyzice těsným sepětím s pedagogikou.

\subsection{Integrační pojetí}

Na počátku tohoto pojetí stál zejména požadavek zařadit do kurikula střední školy moderní fyziku, tj. problém modernizace obsahu výuky (Nezvalová, 2011, s. 175). Modernizační tendence v oblasti fyzikálního vzdělávání souvisejí podle Lepila (2008, s. 88-89) s kritikou školství v USA, která přišla po vypuštění první umělé družice Země bývalým Sovětským svazem (tzv. sputnik šok). Tyto snahy reagovaly na výtky, že školní vzdělávání dostatečně nesleduje úroveň vědeckého rozvoje ve fyzice a že předávané poznatky neodpovídají úrovni vědy ani jejím aplikacím (Lepil, 2008, s. 89). Z hlediska obsahu fyzikálního vzdělávání šlo o zařazení tzv. moderní fyziky, kterou se rozuměly 
zejména fyzikální poznatky 1 . poloviny 20 . století - speciální teorie relativity, kvantová fyzika a fyzika mikrosvěta (Lepil, 2012, s. 89).

V tomto období se v domácí didaktice fyziky silně projevují soudobé zahraniční vlivy. Svůj odraz našly zahraniční modernizační myšlenky v domácí didaktice fyziky už počátkem 60. let 20. století (Lepil, 2008, s. 89). Konkrétně se na jejich realizaci podílel např. J. Fuka, který se významně angažoval v Jednotě československých matematiků a fyziků (JČSMF). Zaměřil se hlavně na inovace obsahu středoškolské fyziky, konkrétně řešení didaktických problémů speciální teorie relativity (Lepil, 2007, s. 223). Důležitou roli ale sehrával celý Kabinet pro modernizaci vyučování fyzice, jehož základ byl položen v JČSMF (Fenclová, 1982, s. 18).

Jako klíčové se tedy v této době ukazovalo převést poznatky moderní fyziky do podoby srozumitelné žákům neboli transformovat obsah fyziky jako vědního oboru do didaktického systému, což můžeme podle Nezvalové (2011, s. 175) ze současného pohledu nazvat ontodidaktickou transformací. Někteří didaktikové fyziky si podle Fenclové (1982, s. 19) začali v této souvislosti uvědomovat, že výuka fyziky je velmi komplikovaný proces, $\mathrm{k}$ jehož postihnutí je třeba využít nejen pedagogiky (resp. obecné didaktiky) a fyziky, ale také dalších oborů - psychologie, matematiky, statistiky, sociologie, kybernetiky, filozofie, historie atd. Metodologie didaktiky fyziky se $\mathrm{v}$ tomto období začala odvozovat $\mathrm{z}$ výše uvedených oborů, napřs. i proto, že v pedagogických disciplínách nebyly $\mathrm{k}$ dispozici dostačující výzkumné metody (Nezvalová, 2011, s. 175). Bylo zřejmé, že žádný z výše uvedených oborů nemohl vyřešit samostatně specifickou problematiku fyzikálního vzdělávání, a proto bylo zdůrazňováno integrační pojetí didaktiky fyziky (její interdisciplinární charakter). Didaktika fyziky tedy začala více využívat výsledků i metod jiných oborů.

Na rozdíl od aplikačního pojetí můžeme u integračního pojetí uvést vlivnou publikaci, která ho reprezentuje. Je jí učebnice Didaktika fyziky: obecné otázky (Kašpar et al., 1978). Dokladem může být následující citace (Kašpar et al., 1978): 
Důležitým pomocným vědním oborem [didaktiky fyziky] je psychologie a pedagogická psychologie ${ }^{7}$, která zjištuje povahu mentálních procesů u žáků, jejich fyzické a mentální zvláštnosti apod. Teorie vyučování fyzice ${ }^{8}$ však je těsně spojena i s logikou, s matematikou a s řadou technických věd, nehledíme-li na ostatní příbuzné př́rodní vědy, s nimiž vyučování fyzice úzce souvisí. (s. 13)

Integrační pojetí respektuje podle Brockmeyerové-Fenclové et al. (2000, s. 27) vědní východisko školního předmětu (proto příklon k označení oborová didaktika) a výuku chápe jako interakci vyučování (činnost učitele) a učení (činnost žáka). Do oblasti oborových didaktik vstupuje $\mathrm{v}$ tomto období i psychodidaktika. Podle Brockmeyerové-Fenclové et al. (2000, s. 27) však ani v tomto pojetí didaktika fyziky (ani další oborové didaktiky) neusiluje o samostatný předmět zkoumání a vlastní metody.

Vrátíme-li se k modernizaci obsahu výuky fyziky, můžeme ji dokumentovat pomocí proměn fyzikálních učebnic. Uved’me nejprve dva příklady učebnic z období před započetím modernizace. Jako první příklad můžeme zmínit učebnice Bělaře et al. (1953) a Chytilové et al. (1953). Podle těchto učebnic sestával fyzikální kurz z mechaniky; akustiky; termiky; elektřiny a magnetismu; optiky a stavby hmoty. Poslední jmenované kapitole, která se nejvíce kryje s moderní fyzikou, je věnováno asi 30 stran z celkového počtu přibližně 600. Druhým příkladem jsou novější učebnice fyziky pro střední všeobecně vzdělávací školy (Fuka et al., 1965; Vanovič et al., 1965; Marek et al., 1966), kde je prostor věnován mechanice; molekulové fyzice a termice; kmitání, vlnění a akustice; elektřině a magnetismu; optice; stavbě atomu a astronomii. Stavbě atomu je věnováno opět zhruba 30 stran (z celkem asi 600).

K výše uvedeným třem dílům byly ale později navíc vytvořeny doplňky (Lepil \& Chytilová, 1973; Fuka, 1974), ve kterých se objevují novější fyzikální témata - např. polovodiče, speciální teorie relativity a fyzika atomového obalu a jádra. Tyto doplňky představují dalších asi 200 stran navíc.

K dalším inovacím obsahu došlo také v učebnicích pro gymnázia z 80. let. Např. na konci prvního dílu (Vachek et al., 1984) zaměřeného na poznatky z mechaniky je zařazena kapitola statická silová pole, kam je zahrnuto jak gravitační, tak elektrické pole, která jsou do jisté míry analogická. Je zde tedy

7 Konkrétně $\mathrm{z}$ oblasti psychologie je $\mathrm{v}$ této publikaci pozornost věnována zejména různým teoriím učení.

$8 \quad \mathrm{Z}$ dnešního pohledu didaktika fyziky, pozn. autora tohoto článku. 
propojena mechanika a elektřina, které byly a jsou často vyučovány odděleně. Obdobně ve třetím dílu (Lepil, Houdek, \& Pecho, 1986) je zařazeno téma kmitání, kam je zahrnuto jak kmitání mechanické, tak střídavý proud. Jde tak o propojení mechaniky a elektromagnetismu. Dochází zde tedy k narušení klasického řazení témat školské fyziky, kdy je pozornost věnována např. mechanice a elektromagnetismu odděleně. Moderní fyzice pak byl věnován zejména čtvrtý díl učebnice (Pišút et al., 1987), kam byla zařazena mimo jiné speciální teorie relativity, kvantová fyzika, astrofyzika a kapitola fyzikální obraz světa. Vazba moderní fyziky na technickou praxi je zdůrazněna ve druhém dílu (Svoboda et al., 1985), kam je zařazeno téma elektrický proud v polovodičích. ${ }^{9}$

Pokud porovnáme aplikační a integrační pojetí, můžeme říci, že integrační pojetí si více uvědomuje vliv společenských faktorů a vliv fyziky jako vědy na výuku fyziky. Na druhou stranu předmět zájmu didaktiky fyziky je stále omezen na školní vzdělávání, tedy zejména na výukový proces na základní a střední škole. Jak aplikační, tak integrační pojetí didaktiky fyziky se vyznačují významným zaměřením na práci učitele v podmínkách školy. $V$ obou pojetích je také kladen důraz na statickou systematizaci izolovaně zkoumaných jevů (Fenclová, 1982, s. 22). Poněkud rezervovaný je rovněž Lepil (2012), který tvrdí, že i když byla řešena také např problematika metod a prostředků výuky (problémové a skupinové vyučování, materiály pro programované učení, využití audiovizuálních prostředků apod.), do běžné praxe škol tyto snahy pronikly jen v malé míře. ${ }^{10}$

\subsection{Komunikační pojetí ${ }^{11}$}

Ačkoliv se po roce 1970 podmínky vědecké práce pod vlivem ideologického tlaku v Československu zhoršily, rozvoj teoretických koncepcí oborových didaktik (včetně didaktiky fyziky) probíhal dále (Brockmeyerová-Fenclová et al., 2000, s. 27). Novější pojetí didaktiky fyziky, které budeme diskutovat, je úzce spjato s tím, že ve 20. století došlo k bouřlivému rozvoji fyziky a z toho důvodu získalo na významu uspořádání a zpracování informací a také jejich společenská komunikace. V tomto smyslu by se podle Fenclové (1982, s. 22) měla rozvíjet i didaktika fyziky. Zatímco dříve uvedená pojetí uvažovala podle

9 Vzhledem k tomu, že zde není cílem sledovat podrobně vývoj učebnic fyziky, odkazujeme dále na článek Lepila (2013), kde jsou podrobnější informace i o novějších učebnicích.

10 Integrační pojetí didaktiky fyziky dále diskutuje Lepil (2012, s. 7-8).

11 Výjimečně se synonymně použivá označení komunikativní pojetí (Kotásek, 2011, s. 235). 
Brockmeyerové-Fenclové et al. (2000, s. 28) především postavení oborových didaktik (včetně didaktiky fyziky) ve spektru věd, tato nová, širší koncepce, nazvaná pojetí komunikační, navázala také na obecnou systémovou analýzu tzv. výchovné sféry (dále ji označujeme jako oblast výchovy a vzdělávání). Aplikace obecných didaktických poznatků (aplikační pojetí) a integrace přístupů relevantních vědeckých disciplín (integrační pojetí) představují v komunikačním pojetí jen dvě z dimenzí oborové didaktiky.

Podle Brockmeyerové-Fenclové et al. (2000, s. 28) a Kotáska (2011, s. 235) začíná být v tomto období didaktika fyziky (a další didaktiky, např. didaktika dějepisu) chápána jako samostatná vědecká disciplína hraniční povahy, která je situovaná mezi určitým oborem (vědeckým nebo jiným) a vědami o výchově a vzdělávání, zejména obecnou didaktikou. První publikace $\mathrm{k}$ tomuto pojetí se objevily kolem roku 1980 (Brockmeyerová \& Tarábek, 2009, s. 283).

Komunikační pojetí vychází podle Kotáska (2011, s. 235) z předpokladu, že mezi určitým oborem lidského myšlení a lidské činnosti (vědeckého poznání, umělecké tvorby, výkonu povolání, praktických činností) a vzdělávací sférou (vyučování a učení ve škole, neformální vzdělávání, incidentální učení) existuje společné pole, které můžeme považovat za specifickou oblast, jíž je vysoce společensky žádoucí se věnovat a kterou je nutné podrobit soustavnému vědeckému zkoumání. Takové vědecké pole nemůže být podle Kotáska (2011, s. 235) samostatně zkoumáno ani pouze představiteli př́slušných oborů (např. fyziky), ani pouze badateli z oblasti věd o výchově a vzdělávání (pedagogy). Lepil (2012, s. 8) k tomu dodává, že mnohé fyzikální poznatky spadají do oblastí nedostupných přímému smyslovému vnímání, a základním problémem se tak stává jejich sdělitelnost. V tomto smyslu je stěžejním úkolem didaktiky fyziky didaktická komunikace, kterou chápeme jako transformaci fyzikálního poznání do sdělitelné podoby (podrobněji dále).

\section{Předmět didaktiky fyziky v komunikačním pojetí}

Předmětem didaktiky fyziky v komunikačním pojetí je didaktická komunikace fyziky, což je souvislý proces předávání a zprostředkování výsledků a metod fyzikálního poznání do vědomí jednotlivcủ, kteří se na vzniku poznání nepodíleli (Brockmeyerová \& Tarábek, 2009, s. 277), neboli proces didaktického zprostředkování poznání v oboru (fyzice) od jeho tvưrců směrem k jeho uživatelům (Kotásek, 2011, s. 235). 
Didaktická komunikace fyziky začíná podle Fenclové (1982, s. 23) již uvnitř fyziky jako vědy, a sice formulací fyzikálních poznatků, hledáním cest jejich sdělitelnosti fyzikům stejné i jiných specializací. Za výchozí bod můžeme tedy považovat vědecký systém fyziky (viz obr. 1, vlevo). Komunikace fyzikálních poznatků pak překračuje hranice fyziky k vědám, které fyzikální poznatky využívají (zejména přírodní vědy a technika). Dále se didaktická komunikace fyziky vydává mimo hranice věd do celé společnosti a speciálně do oblasti výchovy a vzdělávání. Tady je zvlášt' významné předávání fyzikálního poznání mladým lidem ve školách. Výsledky didaktické komunikace fyziky pak vstupují dále do společnosti v podobě znalostí, dovedností, postojů a hodnot lidí.

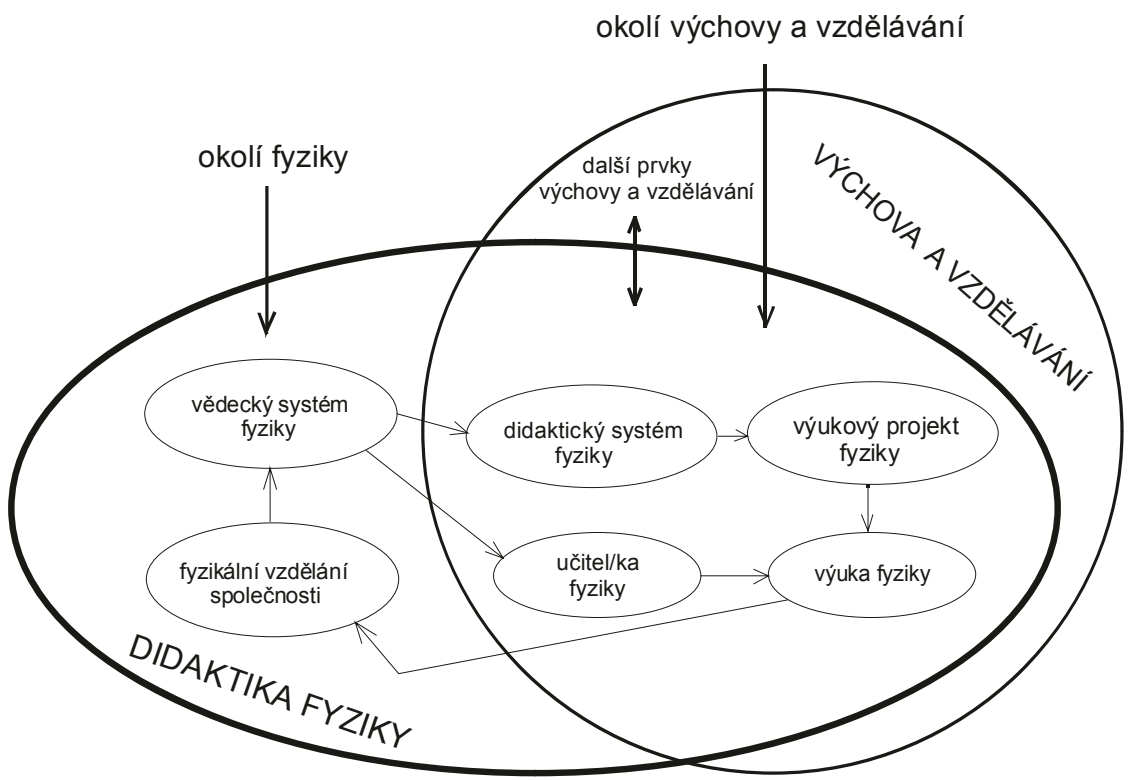

Obrázek 1. Vztah předmětu didaktiky fyziky a oblasti výchovy a vzdělávání. Převzato od Fenclové (1982, s. 24) a upraveno.

Komunikační pojetí tedy mimo jiné umožňuje provádět určité zlaičtění fyziky. Do souvislosti s ním můžeme dát publikace, které dovolují zájemcům věnovat se fyzice i mimo běžnou školní výuku. Máme tím na mysli nejrůz- 
nější popularizační články, knížky a televizní pořady (v současné době také multimediální pořady, internetové stránky a podobně). Ty se často zaměřují na fyziku 20. století (tzv. moderní fyziku). Ze starších uved'me knihu Zajímavá fyzika (Perelman, 1962) nebo seriál Československé televize Okna vesmíru dokořán (spojený s J. Grygarem), z mnoha současných zmiňme např. knihu Trhlina ve stvoření světa (Gleiser, 2012).

Významným postřehem $v$ této souvislosti je, že nakonec se proces předávání fyzikálního poznání vrací zpátky do fyziky a i na něm do jisté míry závisí rozvoj fyziky jako vědy. ${ }^{12}$ Podle Fenclové $(1982$, s. 23) bylo na tento jev upozorněno již v polovině 70 . let 20 . století. Nevěnuje-li se dostatečná pozornost didaktické komunikaci, může být ohrožen vědní obor tím, že ubývá zájemců o studium daného oboru a o vědeckou práci v něm. Kromě nedostatečného personálního zabezpečení pak může daný vědní obor trpět také nedostatkem financí.

Podle Fenclové (1982, s. 26) by měla didaktika fyziky sledovat celou cestu předávání fyzikálního poznání, a prochází tak různými oblastmi (myšlení, zkoumání a vyjadřování). Tyto oblasti označuje jako základní problémové oblasti didaktiky fyziky a formuluje je takto (srov. Fenclová, 1982, s. 26-27; Fenclová et al., 1984, s. 30-32):

- vědecký systém fyziky (z hlediska didaktické komunikace fyzikálního poznání);

- didaktický systém fyziky;

- výukový projekt fyziky a jeho prostředky;

- výukový proces fyziky;

- výsledky výuky fyziky a jejich hodnocení;

- fyzikální vzdělání a jeho uplatnění;

- výchova a vzdělávání učitelů fyziky;

- metodologie a historie didaktiky fyziky.

Na didaktickou komunikaci fyziky, která je předmětem didaktiky fyziky v komunikačním pojetí, můžeme nahlížet tak, že je tvořena určitými fázemi a transformacemi, které úzce souvisejí s výše uvedenými problémovými ob-

12 Viz citát z editorialu Musilové (2012) v úvodu tohoto textu. 
lastmi (více Brockmeyerová \& Tarábek, 2009, s. 279-282; Tarábek \& Záškodný, 2006a, s. 149).

\section{Další souvislosti s komunikačním pojetím}

Brockmeyerová a Tarábek (2009, s. 283) uvažují s ohledem na významný podíl dalších oborů (např. teorie systémů a kognitivních věd) a s ohledem na jejich integraci do teorie didaktické komunikace o tzv. integračně-komunikačním pojetí. V této souvislosti se pokusili Tarábek a Záškodný (2006a, s. 150-155) navázat diskuzí analyticko-syntetické metody, která má odpovědět na otázku, jak přenášet a zprostředkovávat fyzikální poznání, a diskuzí metody strukturovaných pojmově poznatkových systémů, která řeší, $v$ jaké podobě zprostředkovávat toto poznání. Propojením obou metod dochází podle autorů $\mathrm{k}$ přenosu fyzikálního poznání v podobě přiměřené možnostem žáků a v podobě respektující vědecký systém fyziky. Tarábek a Záškodný (2006b, s. 224-227) dále popisují pojmově poznatkové systémy a jejich kognitivní úrovně ve fyzikálním poznávání.

Protože v současné době je fyzikální vzdělávání (i obecněji poznávání) velmi ovlivněno informačně-komunikačními technologiemi, navrhují Nezvalová (2011, s. 176) a Lepil $(2012$, s. 8) označit současné pojetí didaktiky fyziky jako informačně-komunikační pojetí. Zdůraznění vlivu informačně-komunikačních technologií bychom mohli dát do souvislosti s jedním ze čtyř pólů reflexe výchovy, kterým jsou podle Bertranda $\left(1998\right.$, s. 13) pedagogické interakce. ${ }^{13}$ Samotné zdůraznění komunikačních technologií ale nemůžeme považovat za něco zcela nového, protože už $v$ minulosti byl kladen $v$ určitých obdobích důraz např. na vliv filmu a televize ve vzdělávání. Na odpověd', nakolik je vliv ICT kvalitativně a kvantitativně odlišný od těchto předchozích př́padů, si budeme muset zřejmě ještě počkat.

Pokud bychom chtěli alespoň nějakým způsobem diskutovat relevantnost komunikačního pojetí vzhledem k současnému stavu v mezinárodním prostředí, nabízí se porovnat výše uvedené problémové oblasti didaktiky fyziky s oblastmi zájmu nějakého díla, které je reprezentativní v mezinárodním kontextu. Za takové dílo v oboru přírodovědného vzdělávání (kam patří také vzdělávání fyzikální) můžeme považovat International handbook of science

13 Obdobně by bylo možné hledat vztah dalších pojetí didaktiky fyziky (a nejen jí) s ostatními Bertrandovými póly, kterými jsou subjekt, obsah a společnost, a př́slušnými teoriemi vzdělávání. 
education (Fraser \& Tobin, 2003). Ze struktury tohoto díla je patrné, které jsou hlavní oblasti zájmu oboru. Z podrobnější analýzy je potom zřejmé, že jak problémové oblasti didaktiky fyziky (formulované počátkem 80. let v domácím prostředí), tak oblasti zájmu přírodovědného vzdělávání (pocházející z mezinárodního prostředí z počátku 21. století) mají značný průnik (podrobněji Žák, 2013, s. 33-37). Tato značná shoda je dána zřejmě tím, že centrálním pojmem komunikačního pojetí je komunikace, která je chápána komplexně.

\section{Shrnutí a obecnější diskuze vývoje domácí didaktiky fyziky}

Zjednodušeně můžeme proměny jednotlivých pojetí didaktiky fyziky $\mathrm{v}$ českém prostředí a zejména těsnost jejich vztahu na jedné straně $\mathrm{k}$ fyzice a na druhé straně k pedagogice sledovat v obr. 2 . Směrem dolů je orientována časová osa. Pojetí umístěná více vlevo jsou více spjata s fyzikou, poloha vpravo naznačuje těsnější vztah k pedagogickým disciplínám, umístění níže ve schématu znamená těsnější vztah s dalšími obory (odpovídá zároveň novějším pojetím).

Pokud jde o metodické pojetí, pak je jeho těsné sepětí s fyzikou dáno zejména tím, že podstatnou část první poloviny 20 . století nebylo v českém prostředí na vysokoškolské úrovni rozlišováno mezi př́pravou na učitelství fyziky a prípravou $\mathrm{k}$ vědecké práci ve fyzice. $\mathrm{V}$ metodickém pojetí se $\mathrm{v}$ podstatě vychází z toho, že fyzika jasně říká, co je obsahem fyzikálního vzdělávání, a didaktika (metodika) má najít vhodné metody, jak tento obsah naučit. $\mathrm{V}$ tomto období nelze mluvit o plnohodnotné existenci didaktiky fyziky jako vědního oboru.

V aplikačním pojetí vychází didaktika fyziky zejména z obecné didaktiky a vymezuje svůj předmět jako zvláštní případ obecného - školní výuku chápe zejména pomocí obecných didaktických kategorií (Nezvalová, 2011, s. 175). V tomto pojetí se tedy primárně vychází z pedagogických věd a fyzika slouží k tomu, aby se z ní vybral vhodný obsah k realizování určitých pedagogických záměrů (naplnění cílů vzdělávání a výchovy). Didaktika fyziky v aplikačním pojetí je těsněji spjata s pedagogikou. Proto je aplikační pojetí situováno ve schématu výrazně vpravo (směrem k pedagogice). Východiskem aplikačního pojetí je vyučovací předmět, a tudíž didaktika fyziky je označována jako didaktika vyučovacího předmětu - předmětová didaktika. 


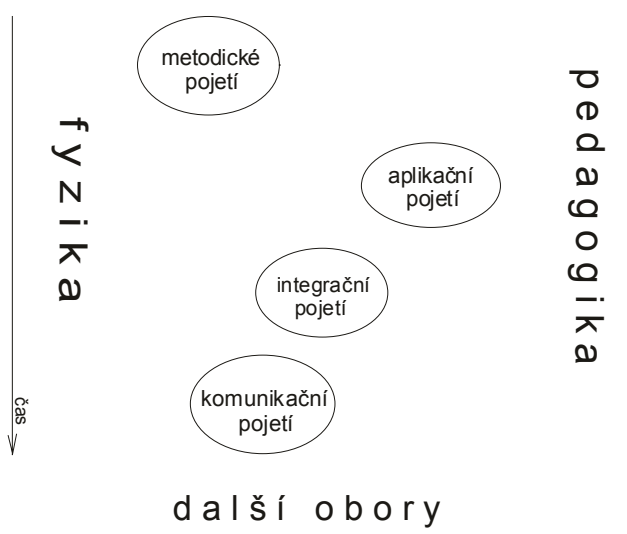

Obrázek 2. Jednotlivá pojetí didaktiky fyziky v poli jiných oborů.

V procesu tzv. modernizace výuky nabývala na významu snaha o transformaci obsahu fyziky jako vědy do didaktického systému. Na této transformaci se však podílela nejen fyzikální věda, ale i další obory, které ovlivňovaly metodologii didaktiky fyziky, což charakterizovalo integrační pojetí didaktiky fyziky posilující její interdisciplinární charakter. V integračním pojetí je těsná vazba didaktiky fyziky jak s pedagogikou, tak fyzikou částečně nahrazena větší propojeností s dalšími obory. Je tak do jisté míry překonáno určité extrémní postavení didaktiky fyziky v těsné blízkosti vždy jednoho z obou výše zmíněných oborů. Tomu odpovídá umístění zhruba uprostřed znázorněného pole v obr. 2.

Další vývojově novější pojetí didaktiky fyziky klade důraz na souvislý proces předávání fyzikálního poznání, který už přesahuje hranice školy a školní výuky (Fenclová, 1982, s. 22-23). Východiskem didaktiky fyziky v komunikačním pojetí je fyzikální poznání, jehož komunikace je nazírána komplexně. Didaktika fyziky je někdy dokonce chápána jako komunikační vědní obor fyziky (Nezvalová, 2011, s. 176). V komunikačním pojetí se didaktika fyziky částečně vrací v pomyslném poli více $\mathrm{k}$ fyzice (didaktická komunikace fyziky začíná uvnitř fyziky), ale v úvahu je brán také vliv pedagogických věd a dalších oborů. $V$ komunikačním pojetí je východiskem příslušný vědní obor fyzika, a je tedy přiléhavější označit didaktiku fyziky za oborovou didaktiku (Lepil, 2012, s. 8). 
Komunikační pojetí bylo v minulosti např. deklarováno jako východisko řešení úkolu s názvem Model perspektivního pojetí výuky fyziky, jehož hlavní výstupy jsou shrnuty v publikaci Fenclové et al. (1984).V souvislosti s řešením tohoto úkolu byla vypracována řada dílčích studií (podrobněji Fenclová et al., 1984, s. 161-162). Z díla je patrné, že pozornost je věnována také problému modernizace (Fenclová et al., 1984, s. 72-79), která je ve svém počátku spojena s integračním pojetím. Objevuje se zde také moment integrace obsahu různých př́rodních věd, a to v podobě návrhu kurzu Stavba hmoty, při jehož prípravě a rozpracování se volalo po spolupráci didaktiků všech prŕrodních věd (Fenclová et al., 1984, s. 117). Je tedy zřejmé, že ani v rámci řešení tohoto úkolu se neustoupilo od inovací (modernizace) obsahu; naopak se vyvíjely v těsné souvislosti s pojetím komunikačním.

Můžeme poznamenat, že i v dalších oborových didaktikách docházelo k více či méně obdobným proměnám jejich pojetí jako $\mathrm{v}$ př́ípadě didaktiky fyziky (Píšová, 2011, s. 147). Lze rovněž souhlasit s Píšovou (2011, s. 147), že komunikační pojetí patří ke koncepcím, které nejvýznamnějším způsobem ovlivňují současné didaktické myšlení v České republice, a to v různých oborech. Ke komunikačnímu pojetí odkazuje v rámci didaktik sociálně-humanitních oborů také např. Beneš (2011, s. 201), když zdůrazňuje, že didaktice dějepisu př́ísluší zkoumání sociální komunikace historických informací, a to se zvláštním přihlédnutím ke školnímu prostředí. Komunikační pojetí také rezonuje s názorem, že výzkumná činnost a všechny formy vzdělávacích procesů jsou určitou podobou komunikace.

Jednotlivá pojetí oborových didaktik a jejich proměny ukazují, že daná oborová didaktika je pod vlivem jak oboru (např. fyziky), tak pod vlivem pedagogických disciplín a dalších oborů. $V$ různých obdobích však byly tyto vlivy různé a mají zřejmě zcela konkrétní důsledky pro oborově didaktické myšlení určitého období. Svoji roli v tomto smyslu hraje také institucionální př́slušnost daných didaktických pracovišt'. Např. v současné době v České republice se vzdělávání budoucích učitelů a učitelek fyziky jak pro ZŠ, tak pro SŠ uskutečňuje podle Žáka (2013, s. 67-68) celkem na 11 pracovištích, z toho v 7 prrípadech se jedná o katedru, resp. oddělení katedry na př́rodovědeckých fakultách (příp. matematicko-fyzikální fakultě), ve 3 př́padech o fakulty pedagogické a $\mathrm{v} 1$ př́ípadě o fakultu přírodovědně-humanitní a pedagogickou. Převažují tedy pracoviště mimo pedagogické fakulty. Lze očekávat, že to s sebou celkem přirozeně přináší poněkud větší důraz na fyzikální obsah než 
na sociálně-humanitní složku (pedagogika, psychologie apod.). Domníváme se, že je vhodné si naznačené vlivy uvědomit, a pak je možné jich využít k obohacování oborových didaktik. Kladou sice na oborové didaktiky určitou dvojí náročnost, ale poskytují zároveň dvojí možnost růstu. Není nutné hledat v působení obou hlavních vlivů (oborového a pedagogicko-psychologického) rozpor, ale spíše jejich komplementaritu.

Je otázkou, jaké je dominující pojetí didaktiky fyziky, příp. jiných oborových didaktik v současnosti v České republice. Domníváme se, že přes vliv komunikačního pojetí je třeba připustit, že také ostatní zmíněná pojetí se do určité míry uplatňují i v současnosti. Koneckonců jak bylo zmíněno výše, ani komunikační pojetí není v přímém rozporu s dřívějším aplikačním a integračním pojetím, ale chápe je jako dílčí součásti sebe sama. Dokonce i vývojově nejstarší metodické pojetí nebylo zcela opuštěno; stačí připomenout, že v některých pracích vznikajících na oborově didaktických pracovištích je (často bohužel) pozornost věnována otázkám konkrétních metodických návrhů, jak realizovat výuku, aniž by byly v dostatečné hloubce a šíři diskutovány např otázky podmínek a zejména cílů a celkového smyslu takového konání. Současný stav by tedy bylo možné zřejmě charakterizovat jako situaci koexistence různých pojetí s tím, že komunikační pojetí je spíše než současným stavem určitým vývojovým trendem, kterým by se česká didaktika fyziky mohla ubírat.

Zdá se totiž, že komunikační pojetí můžeme považovat za dosavadní koncepční vrchol vývoje domácí didaktiky fyziky, byt' je jeho dosažení od nás v současné době vzdáleno zhruba 30 let (zásadní publikací je tu dílo Fenclové, 1982). Není pravda, že by se od té doby v domácí didaktice fyziky nic nedělo; naopak. Pro 90. léta byla zřejmě typická (obdobně jako v mnoha jiných oblastech lidského konání) snaha většího odpoutání od minulého, která bohužel často nevycházela z hlubší analýzy toho, co bylo vykonáno, ale spíše jen z pocitu, že je třeba dělat věci jinak. Možná přemíra kusých vlivů ze zahraničí ve spojení $\mathrm{s}$ absencí nadhledu nad minulým vývojem $\mathrm{v}$ domácím prostředí vedly ke koncepční stagnaci v oboru. Možná právě nyní nastává vhodné období k pokročení v koncepčních a metodologických otázkách domácí didaktiky fyziky.

Pokud bychom se pokusili alespoň v náznaku konfrontovat komunikační pojetí se specializačními trendy, které uvádí Janík (2009, s. 658), můžeme si všimnout, že toto pojetí má průnik s trendem označeným pojmem oborová didaktika jako epistemologická analýza oboru. Předmět výzkumu takto pojaté 
oborové didaktiky - didaktické transformace a didaktický systém oboru - je totiž zahrnut v problémových oblastech didaktiky fyziky, jak je vidí komunikační pojetí (viz podkapitolu 1.4). Ačkoliv se tato souvislost jeví jako zřejmá, zasluhovala by hlubší rozbor, obdobně jako souvislost dalších specializačních trendů (Janík, 2009; Slavík \& Janík, 2005) a současného stavu domácí didaktiky fyziky.

Jak už bylo naznačeno v úvodu, porovnání vývoje didaktiky fyziky v zahraničí a u nás vydá na samostatnou studii. Důvodem je zejména to, že vývoj v zahraničí probíhal a probíhá v různých kulturních oblastech do jisté míry odlišně. Dále je kromě komparace s physics education research třeba hledat souvislosti s obecněji pojatým science education research, který je typický pro angloamerické prostředí. Připomeňme, že v některých obdobích byl zahraniční vliv na domácí didaktiku fyziky poměrně silný a jednoznačný (integrační pojetí a modernizace), naproti tomu vliv zahraničního vývoje na formulování např komunikačního pojetí není podle našeho názoru dostatečně vyjasněn. Pokud jde o konkrétní národní vlivy, které se uplatňovaly při domácím vývoji, můžeme obecně poukázat zejména na vliv německé, sovětské (ruské), polské a mad’arské didaktiky fyziky a také na vlivy z Velké Británie a USA. Specifická je souvislost české a slovenské didaktiky fyziky, které se do začátku 90. let 20. století vyvíjely společně v rámci československé tradice. Domníváme se, že všechna výše uvedená témata si zaslouží pozornost.

Zamyslíme-li se nad strategickým cílem výzkumu, jehož součástí je tato studie a který jsme $\mathrm{v}$ úvodu formulovali jako reflektovat vývoj didaktiky fyziky v České republice a v zahraničí, přispět k pochopení jejího současného stavu a formulovat prognózu jejího budoucího vývoje, nabízí se níže uvedená struktura budoucí práce:

- Provést systematickou reflexi dosavadního vývoje didaktiky fyziky (příp. příbuzných didaktik) v zahraničí (jednak mezinárodní kontext, jednak sledovat národní vývoj ve vybraných relevantních zemích) a uvést tento vývoj do vztahu s domácí situací.

- Realizovat studii současného stavu domácí didaktiky fyziky, mimo jiné na základě porovnání se zahraničím a analýzy současné české odborné publikační produkce (včetně disertačních prací).

- Provést prognózu budoucího vývoje didaktiky fyziky v České republice, zejména na základě uvedených předchozích studií. 
Tuto studii tedy chápeme jako informační přehledovou podporu výše navržených výzkumů, která jednak rekapituluje, jednak systematizuje a dále otvírá nové otázky spojené s koncepcí, teorií a metodologií didaktiky fyziky.

\section{Literatura}

Bělař, A., Hlavička, A., Lehar, F., Pavlík, B., \& Pírko, Z. (1953). Fysika pro čtvrtou třídu gymnasií. Praha: Státní pedagogické nakladatelství.

Beneš, Z. (2011). Co je (dnes) didaktika dějepisu? Pedagogická orientace, 21(2), 193-206.

Bertrand, Y. (1998). Soudobé teorie vzdělávání. Praha: Portál.

Brockmeyerová-Fenclová, J., Čapek, V., \& Kotásek, J. (2000). Oborové didaktiky jako samostatné vědecké disciplíny. Pedagogika, 50(1), 23-37.

Brockmeyerová, J., \& Tarábek, P. (2009). Struktura didaktické komunikace fyziky. Matematikafyzika-informatika, 18(5), 277-284.

Fenclová, J. (1982). Úvod do teorie a metodologie didaktiky fyziky. Praha: Státní pedagogické nakladatelství.

Fenclová, J., Bednařík, M., Půlpán, Z., \& Svoboda, E. (1984). K perspektivám fyzikálního vzdělávání $v$ didaktickém systému přírodních věd. Praha: Academia.

Fraser, J. B., \& Tobin, K. G. (Eds.). (2003). International handbook of science education. Dordrecht: Kluwer Academic Publishers.

Fuka, J. (1974). Doplněk $k$ učivu fyziky pro IV. ročník gymnasia. Praha: Státní pedagogické nakladatelství.

Fuka, J., Klimeš, B., Lepil, O., Široký, J., Vanýsek, V., \& Rudolf, V. (1965). Fyzika pro III. ročník střední všeobecně vzdělávací školy (pro III. a IV. ročník gymnasia). Praha: Státní pedagogické nakladatelství.

Gleiser, M. (2012). Trhlina ve stvoření světa. Nová vize života v nedokonalém vesmíru. Praha: Dokořán, Argo.

Chytilová, M., Pavlík, B., Šoler, K., \& Vlach, B. (1953). Fysika pro třetí třídu gymnasií. Praha: Státní pedagogické nakladatelství.

Janás, J., \& Kolářová, R. (2007). K stému výročí narození RNDr. Marty Chytilové, CSc. Matematikafyzika-informatika, 16(10), 602-605.

Janík, T. (2009). Oborové a předmětové didaktiky. In J. Průcha (Ed.), Pedagogická encyklopedie (s. 656-660). Praha: Portál.

Janík, T., \& Slavík, J. (2007). Vztah obor - vyučovací předmět jako metodologický problém. Orbis scholae, 1(1), 54-66.

Janík, T., \& Stuchlíková, I. (2010). Oborové didaktiky na vzestupu: přehled aktuálních vývojových tendencí. Scientia in educatione, 1(1), 5-32.

Kansanen, P. (2007). Oborové didaktiky jako základ znalostní báze pro učitele - nebo tomu budeme raději říkat pedagogical content knowledge? In T. Janík (Ed.), Pedagogical content knowledge nebo didaktická znalost obsahu? (s. 11-22). Brno: Paido.

Kašpar, E. (1960). Kapitoly z didaktiky fyziky I. Praha: Státní pedagogické nakladatelství.

Kašpar, E., Hniličková-Fenclová, J., Lepil, O., Skalický, V., Vachek, J., \& Vlach, B. (1978). Didaktika fyziky: obecné otázky. Praha: Státní pedagogické nakladatelství. 
Kotásek, J. (2011). Domácí a zahraniční pokusy o obecné vymezení předmětu a metodologie oborových didaktik. Pedagogická orientace, 21(2), 226-239.

Kuhn, T. S. (2008). Struktura vědeckých revolucí. Praha: OIKOYMENH.

Lepil, O. (2007). Odkaz díla prof. PaedDr. Josefa Fuky v didaktice fyziky. Matematika-fyzikainformatika, 17(4), 218-225.

Lepil, O. (2008). K vývoji didaktiky fyziky. Matematika-fyzika-informatika, 18(2), 82-92.

Lepil, 0. (2012). Vybrané kapitoly k modulu Didaktika fyziky. Olomouc: Univerzita Palackého v Olomouci.

Lepil, O. (2013). K vývoji učebnic fyziky pro střední školu gymnaziálního typu. Matematikafyzika-informatika, 22(4), 16-3014.

Lepil, O., Houdek, V., \& Pecho, A. (1986). Fyzika pro III. ročník gymnázií. Praha: Státní pedagogické nakladatelství.

Lepil, O., \& Chytilová, M. (1973). Doplněk k učivu fyziky pro III. ročník gymnasia. Praha: Státní pedagogické nakladatelství.

Marek, J., Chytilová, M., Kašpar, E., \& Vanýsek, V. (1966). Fyzika pro I. ročník střední všeobecně vzdělávací školy. Praha: Státní pedagogické nakladatelství.

Mareš, J., \& Honsnejmanová, I. (2011). Diskuse o pedagogických časopisech v České republice. Pedagogická orientace, 21(1), 104-113.

Musilová, J. (2012). Editorial. Československý časopis pro fyziku, 62(5-6), 279.

Musilová, J. (Ed.). (2012). Fyzikální vzdělávání [Monotematické číslo]. Československý časopis pro fyziku, 62(5-6).

Nezvalová, D. (2011). Didaktika fyziky v České republice: trendy, výzvy a perspektivy. Pedagogická orientace, 21(2), 171-192.

Perelman, J. I. (1962). Zajímavá fyzika. Praha: Mladá fronta.

Píšová, M. (2011). Didaktika cizích jazyků: otázky identity. Pedagogická orientace, 21(2), 142-155.

Pišút, J., Frei, V., Fuka, J., Lehotský, D., Široký, J., Tomanová, E., \& Vanýsek, V. (1987). Fyzika pro IV. ročník gymnázií. Praha: Státní pedagogické nakladatelství.

Průcha, J. (2009). Pedagogická věda v ČR. In J. Průcha (Ed.), Pedagogická encyklopedie (s. 633-638). Praha: Portál.

Slavík, J. (2011). K předmětu didaktik v estetických oborech vzdělávání. Pedagogická orientace, 21(2), 207-225.

Slavík, J., \& Janík, T. (2005). Významová struktura faktu v oborových didaktikách. Pedagogika, 55(4), 336-353.

Slavík, J., \& Janík, T. (2009). Obsah, subjekt a intersubjektivita v oborových didaktikách. Pedagogika, 59(2), 116-135.

Stehlíková, N., \& Tichá, M. (2011). Didaktika matematiky a její proměny. Pedagogická orientace, 21(2), 156-169.

Stuchlíková, I., \& Janík, T. (Eds.). (2011). Oborové didaktiky: bilance a perspektivy [Monotematické číslo]. Pedagogická orientace, 21(2).

Svoboda, E. (2007). Ke 100. výročí narození prof. RNDr. Emila Kašpara, DrSc. Matematikafyzika-informatika, 16(9), 534-538.

Svoboda, E., Bartuška, K., Baník, I., Kotleba, J., \& Tomanová, E. (1985). Fyzika pro II. ročník gymnázií. Praha: Státní pedagogické nakladatelství.

14 Jedná se o stránky přílohy, které jsou původně označeny jako P16-P30. 
Tarábek, P., \& Záškodný, P. (2006a). Didaktická komunikace fyziky a její aplikace. Matematikafyzika-informatika, 16(3), 146-157.

Tarábek, P., \& Záškodný, P. (2006b). Didaktická komunikace fyziky a její aplikace. Matematikafyzika-informatika, 16(4), 224-227.

Vachek, J., Bednařík, M., Klobušický, K., Maršák, J., Novák, J., \& Šabo, I. (1984). Fyzika pro I. ročník gymnázií. Praha: Státní pedagogické nakladatelství.

Vanovič, J., Sokol, E., Thern, L., \& Vlach, B. (1965). Fyzika pro II. ročník střední všeobecně vzdělávací školy. Praha: Státní pedagogické nakladatelství.

Váňová, R. (2000). Vědy o výchově na stránkách Pedagogiky (K 50. výročí vzniku časopisu). Pedagogika, 50(4), 313-339.

Žák, V. (2013). Různá pojetí didaktiky fyziky u nás a v zahraničí (Diplomová práce). Praha: Filozofická fakulta Univerzity Karlovy.

\title{
Autor
}

RNDr. Mgr. Vojtěch Žák, Ph.D., Univerzita Karlova v Praze, Matematicko-fyzikální fakulta, Katedra didaktiky fyziky, V Holešovičkách 2, 18000 Praha 8, e-mail: Vojtech.Zak@mff.cuni.cz

\section{Historical development of approaches to didactics of physics in the Czech Republic}

\begin{abstract}
The purpose of the review is to describe the approaches to the didactics of physics which appeared in the Czech Republic during its development, and to discuss especially the relationships between the didactics of physics and other fields. It should be beneficial to the understanding of the current situation and to the prognosis of the future development. The main, part of the paper includes the characteristics of particular approaches of the Czech didactics of physics. In chronological order, these are the methodological, application, integration and communicative approaches. The summary and concluding discussion deals with the relationships between the didactics of physics and the subject of physics itself, pedagogy and other fields. It seems that the methodological approach is closely connected to physics, while the application approach comes primarily from pedagogy. The integration approach strives for the utilisation of other scientific fields to develop the didactics of physics. This paper reveals that the most elaborate is the communicative approach. This approach belongs to the concepts which influence the current didactical thinking in the Czech Republic to the highest extent in various fields (including within the didactics of socio-humanist fields). In spite of the communicative approach, it is necessary to admit that the other mentioned approaches are also, to a certain extent, employed and co-exist.
\end{abstract}

Keywords: approach to didactics of physics, didactics of physics, subject didactics 